\title{
JARI SELAYAK DURI
}

\author{
Aulia Puspaning Galih \\ Universitas Brawijaya \\ auliapuspa@ub.ac.id
}

\begin{abstract}
Social media, as the name implies, is a media for people to socialize with the others, with borderless space and time, over the Internet. Facebook is one of Indonesian favorite social media. Indonesian does a lot of activities on Facebook, such as posting and commenting on other people posts. One of the most popular features on Facebook is the sharing feature. It can share post or link from online media or other people's post to their own account. The ease of using the share features, it also raises many cases. The case of indignation expression of Danish badminton players against the threat of murder directed against them, until the case of defamation of the President of Indonesia became a real example of the effects of these features. Many of those kinds of cases result in social punishment, even prison. Law of The Republic of Indonesia Number 11 year 2008 about Electronic Information and Transaction which had been revised on 2016, still can not solve social problems which occur on the Internet. In fact, the Act alone will not be enough to solve social problems. Actually, what society needs is more knowledge about digital literacy.
\end{abstract}

\begin{abstract}
Abstrak
Mediasosial, sepertinamanya, adalahmediabagimasyarakatuntukbersosialisasidengan orang lain tanpa dibatasi ruang dan waktu melalui jaringan internet. Salah satu bentuk media sosial yang paling banyak digunakan saat ini, terutama oleh masyarakat Indonesia, adalah jejaring sosial Facebook. Masyarakat Indonesia melakukan banyak kegiatan di situs jejaring sosial tersebut, seperti mengunggah tulisan dan berkomentar pada suatu unggahan. Salah satu fitur yang digemari di Facebook adalah fitur bagikan yang berfungsi agar pengguna dapat membagi tautan dari orang lain keakun pribadi mereka dengan pengaturan tertentu. Adanya kemudahan dalam menggunakan fitur bagikan tersebut, ternyata malah menimbulkan banyak kasus. Kasus ungkapan kemarahan pemain bulutangkis asal Denmark terhadap ancaman pembunuhan yang ditujukan kepada mereka, hingga kasus penghinaan Presiden Indonesia menjadi contoh nyata dari efek fitur tersebut. Tidak jarang masalah yang ada di jejaring sosial berujung pada hukuman sosial,bahkan dapat masuk dalam ranah hukum pidana. UndangUndang Informasi dan Transaksi Elektronik yang telah direvisi pada akhir tahun 2016, ternyata tidak dapat mengatasi masalah sosial yang terlanjur terjadi di internet. Faktanya, Undang-undang saja tidak akan cukup untuk mengatasi masalah sosial. Sebenarnya, yang lebih dibutuhkan masyarakat adalah pengetahuan tentang literasi digital.
\end{abstract}

Keywords: Hatespeech, Social Media, Digital Literacy 


\section{Pendahuluan}

Pada saat ini, hampir seluruh aktivitas manusia berpusat pada teknologi seperti internet. Dengan jumlah pengguna Internet di seluruh dunia yang lebih dari 3.8 miliar (Ismarani, 2017), tidak mengherankanapabila cara berkomunikasi masyarakat pun turut berubah seiring dengan berkembangnya Internet. Perubahan cara berkomunikasi ini, paling terasa terjadi pada media sosial. Blogging, microblogging (Blogger, Twitter), aplikasi chatting (WhatsApp, Line), layan-an berbagi foto dan video (Instagram, Youtube), dan jejaring sosial (Facebook, MySpace), menjadi media sosial yang banyak digunakan untuk bersosialisasi dan berkomunikasi.

Pada era teknologi, media sosial bukan hanya berfungsi sebagai alat komunikasi satu arah (one-to-many), tetapi telah berkembang menjadi alat komunikasi banyak arah (manyto-many). Pada media sosial, pengguna tidak hanya dapat mengunggah informasi, pengguna juga dapat mengomentari, dan membagikan informasi yang berasal dari pemikirannya sendiri atau pemikiran orang lain. Komunikasi banyak arah ini membuat pengguna internet tidak hanya dapat menerima informasi, tetapi juga memproduksi informasi (produce; Benkler, 2002). Pengguna internet dapat menuliskan ide-ide yang dimilikinya, menyalurkan opini mengenai suatu hal, atau bahkan memberikan kritik dan saran terhadap pihak tertentu. Kegiatan prosumer inilah yang menjadi ladang subur bagi jurnalisme daring.

Jurnalismedaring menggusur jurnalisme luring secara cepat dan konstan. Media massa yang awalnya hanya terbit secara tercetak (surat kabar, majalah, tabloid, dll) atau secara elektronik (televisi dan radio), kini bergeser ke media daring melalui internet. Jurnalisme daring saat ini bukan hanya dilakukan oleh media massa dan jurnalis profesional, tetapi juga dilakukan oleh para pengguna sosial media yang secara umum disebut prosumer. Prosumer berasal dari istilah production by consumers (Toffler, 1980), yang berarti adalah usaha seseorang untuk mengonsumsi sekaligus memproduksi informasi sehingga peran penyedia informasi dan pengonsumsi informasi menjadi buram. Setiap pengguna media daring merancang sendiri jenis informasi yang akan diunggahnya dengan mengharapkan informasi yang ditulisnya dapat bermanfaat bagi orang lain.

Pengguna media sosial yang melakukan jurnalisme daring terkadang tidak menyantumkan sumber informasi yang valid agar dapat dilacak kembali. Seringkali tulisan mereka hanya merupakan kumpulan opini, opini pribadi mereka mengenai suatu hal. Semudah mereka mengunggah informasi, semudah itu pula orang lain dapat membagikan informasi tersebut ke akun pribadi media sosial mereka. Adanya kemudahan dalam menggunakan tombol 'bagikan' tersebut, membuat informasi yang belum tentu benar dapatdengan mudah menjadi viral di media sosial.Viralnya sebuah berita membuat akun atau laman yang membuat beritapun menjadi terkenal.

Adanya berita viral yang ternyata lebih dapat menarik perhatian pembaca, membuat para pengguna media sosial, atau bahkan jurnalis profesional, terkadang berusaha untuk membuat suatu berita dengan tujuan utama yaitu 'keviralan'. Kemudahan dalam mengakses informasi, semakin memuluskan jalan mereka untuk menyebarkan informasi agar menjadi viral. Keviralan suatu berita sebenarnya tidak hanya dipengaruhi oleh konten dan judul berita. Publikasi yang luas, banyaknya kerjasama daring, dan adanya fitur 'bagikan' pada berbagai media sosial, dapat membuat suatu berita menjadi viral karena telah diketahui banyak orang. Berawal dari sinilah, keviralan berita menjadi aspek penting yang ikut 'diperjuangkan' oleh para pengguna media sosial atau bahkan jurnalis profesional. Tujuan yang salah inilah yang menyebabkan tergadainya kualitas dan kredibilitas informasi yang seharusnya menjadi patokan utama dalam membuat berita.

Pengguna media sosial, atau bahkan jurnalis profesional,banyak yang melupakan etika penulisan berita, mulai dari penggunaan bahasa hingga tujuan jurnalisme yang seharusnya mencerdaskan masyarakat (Sumadiria, 2006). Hal ini mereka lakukan 
hanya karena ingin mendapatkan banyak pembaca. Media daring yang selalu dituntut untuk menyajikan berita secara cepat, terkadang membuat mereka kehilangan fokus untuk menomersatukan kebenaran dari berita yang mereka buat. Jika fenomena ini terus terjadi, maka akan banyak beritaberita yang belum tentu benar informasinya, beredar secara luas dan menjadi kabar viral. Kabar viral yang belum tentu benar tentu saja dapat berpeluang untuk merugikan beberapa pihak yang merasa keberatan dengan adanya berita tersebut.

Fenomena keviralan sebuah berita biasanyadipengaruhiolehkebiasaanpembaca yang tidak membaca dan memahami berita secara keseluruhan. Kebanyakan pembaca hanya melihat judul dan meninggalkanya laman terkait begitu saja. Terlebih lagi, banyak pembaca justru menyukai informasi yang diceritakan oleh orang lain, bukan informasi yang ia peroleh sendiri. Informasi yang orang lain ceritakan dari berita yang di baca, tentu saja tidak $100 \%$ benar karena biasanya informasi yang disampaikan tersebut akan 'dibumbui' dengan opini atau kepentingan pribadi. Pemahaman informasi tentu akan berbeda jika pembaca mau membaca dan menganalisis sendiri. Halhal inilah yang menyebabkan sebuah berita akan sangat mudah menjadi viral walaupun sebenarnya kontennya tidak terlalu penting.

Kebiasaan pembaca yang cenderung kurang teliti dan hanya mementingkan rasa penasaran, terkadang dimanfaatkan oleh media daring untuk meraup keuntungan. Banyak media daring yang membuat tajuk berita agar terkesanambigu dan dengan sengaja membagikannya kemedia sosial agar berita tersebut menjadi viral. Banyaknya pembaca yang memiliki kebiasaan hanya melihat judul tetapi tidak membaca berita secara keseluruhan,akan dengan mudah berkomentar mengenai topik tersebut padahal belum tentu ia mengerti apa sebenarnya informasi yang dibahas. Judul berita yang cenderung menggiring opini publik, membuat pengguna Internetdapat dengan mudah mengujarkan kebencian pada pihak tertentu.
Kasus penistaan agama yang dilakukan oleh mantan Gubernur DKI Jakarta Basuki Tjahja Purnama yang akhirnya merambah keranah SARA, menjadi salah satu contoh kasus karena media sosial. Kasus tersebut pada awalnya hanya berupa sebuah pidato gubernur di Pulau Seribu, yang kemudian diunggah oleh salah satu penonton yang hadir pada acara tersebut. Dengan pengunggahan video ke media sosial, secara otomatis akan menjadikan informasi yang ada pada video tersebut menjadi bahan konsumsi publik. Dengan adanya berbagai alasan, termasuk alasan politik yang sedang sensitif dibicarakan pada saat itu, membuat video tersebut berpotensi menjadi berita yang bisa saja disalahgunakan oleh pihak-pihak tertentu.

Adanya kasus ini membuat pihak yang bersangkutan dapat menjadi objek utama pengujaran kebencian yang dilontarkan di media sosial. Masyarakat yang tidak ada kaitannya dengan kasus tersebut ikut menjadi bahan cemoohan dan bahkan mendapatkan ancaman perkosaan (Anya, 2017). Berita yang telah dibagikan seribu kali dan mendapatkan 154 komentar pada laman media daring thejakartapost. com ini hanyalah satu dari sekian banyak ujaran kebencian yang merambah ke ranah hukum. Dari kasus tersebut, dapat kita sadari bahwa media sosial dapat menjadi 'pedang bermata dua'. Di satu sisi, media sosial dapat memudahkan sosialisasi dan komunikasi antar pengguna, akan tetapi di sisi lain, media sosial dapat digunakan sebagai 'senjata' untuk melontarkan ujaran kebencian yang dapat merugikan orang lain karena mudahnya akses dan jaringan daring yang sangat luas.

Banyaknya kasus yang terjadi akibat media sosial, terus 'menggelitik' pemerintah untuk segera mengambil tindakan tegas untuk menyelesaikan permasalahan ini. Undang-Undang Informasi dan Transaksi Elektronik sebenarnya sudah dibuat oleh pemerintah untuk mengatur beredarnya informasi dan transaksi elektronik yang ada di Internet. Undang-Undang ini dibuat agar warga net dapat merasa lebih 
terlindungi dalam menjalankan aktivitasnya di media sosial. Tidak hanya pemerintah, kepolisianpun ikut membuat peraturan berupa Surat Edaran tentang Penanganan Ujuran Kebencian. Surat Edaran yang dikeluarkan oleh Kepala Kepolisian Republik Indonesia pada saat itu, Drs. Badrodin Haiti, berisi tentang tindakan pencegahan dan penanganan ujaran kebencian.

Undang-Undang dan Surat Edaran yang dibuat oleh pemerintah pada dasarnya hanya merupakan 'pagar pembatas' dan pedoman bagi masyarakat agar dapat lebih bijak dalam melakukan aktivitasnya dimedia sosial. Banyaknyajumlah media sosial, media daring, dan pengguna internet yang ada di Indonesia, harusnya diikuti dengan kemampuan literasi digital yang mencukupi. Pentingnya literasi digital seharusnya disosialisasikan secara lebih maksimal agar kemudahan prosume ini tidak menjadi boomerang bagi masyarakat Indonesia sendiri.

\section{HASIL DAN PEMBAHASAN}

\section{Jebakan Klik Pada Media Daring}

Kita sadari atau tidak, perkembangan teknologi merupakan salah satu pendorong cepatnya proses peradaban manusia dimasa modern. Kemajuan peradaban ini membuat kebutuhan manusia semakin meningkat dan beraneka ragam. Salah satu kebutuhan manusia yang memiliki tingkat pemenuhan cukup tinggi adalah kebutuhan akan informasi. Kebutuhan informasi telah bertransformasi menjadi salah satu kebutuhan pokok yang menunjang aktivitas manusia di masa modern. Kebutuhan informasi ini mendorong tersedianya mediamedia yang dapat digunakan untuk saling bertukar informasi. Media-media ini membentuk sebuah komunitas 'tak kasat mata' yang bentuk fisiknya tidak ada, tetapi pengaruh dari informasinya sangat terasa. Masing-masing media ini membuat pola komunikasi dan sosialisasi yang berbeda sehingga membangun konvergensi antar media guna memperluas jangkauan.

Henry Jenkins (2006:423) menjelaskan bahwa yang dimaksud dengan konvergensi media adalah hadirnya konten dari berbagai saluran multimedia yang mana menciptakan hubungan yang kompleks dan memunculkan budaya partisipatif. Konvergensi media ini paling banyak terjadi di media sosial yang mana telah menjadi pusat interaksi antar manusia disegala menjuru dunia. Media sosial telah berubah menjadi tempat strategis untuk saling berbagi informasi dengan kemudahan 'sekali klik'.

Adanya konvergensi media memungkinkan suatu tautan berita akan terhubung dengan tautan berita lainnya. Semakin banyak suatu berita berkonvergensi dengan media lain, maka semakin banyak pula jumlah pembaca tautan berita tersebut. Dengan banyaknya jumlah pembaca, secara otomatis keuntungan finansial dari pembuat berita akan terus meningkat. Keuntungan inilah yang terkadang menjadi fokus utama dari para pembuat berita yang tidak bertanggungjawab. Perubahan fokus pembuatan berita yang pada awalnya mengutamakan kualitas isi berita menjadi mengutamakan jumlah pembaca, membuat kualitas informasi yang ada cenderung menurun. Hal ini tentunya akan merugikan pembaca yang menginginkan informasi berkualitas secara cepat dan tepat.

Pada saat ini, media daring telah berubah fungsi menjadi lahan subur bagi praktik konvergensi media yang telah disalah artikan. Media daring ini telah berubah menjadi sebuah tren bagi orang-orang yang tidak sepenuhnya paham dengan apa itu konsep media sosial. Ketidakpahaman yang dimiliki oleh sebagian pembaca, dijadikan celah bagi media daring untuk mendapatkan keuntungan sebesar-besarnya. Kebiasaan yang salah dalam bersosial media, menjadi salah satu faktor terbesar yang mendorong suksesnya 'permainan' ini.

Banyaknya 'permainan' di media daring sebenarnya berawal dari kebiasaan pembaca yang kebanyakan membaca berita hanya dari judulnya saja. Pembaca cenderung lebih tertarik dengan berita yang mempunyai judul menarik tanpa mengecek terlebih dahulu bagaimana isinya.Hal tersebut dimanfaatkan oleh jurnalis dan media daring untuk 
membuat berita yang terkesan menjebak pembaca. Para jurnalis media daring berlomba-lomba membuat judul berita yang memuat pertanyaan, kontroversial, dan bahkan menantang pembaca untuk membuka tautan berita tersebut. Tindakan ini disebut clickbait atau jebakan klik yang mana telah merebak sejak dua tahun terakhir.

Jebakan klik dapat diartikan sebagai ketidaksesuaian judul berita dengan isi berita. Praktik jebakan klik ini menjadi salah satu strategi berbisnis dan bermedia sosial para pengguna media sosial yang mempunyai kepentingan tertentu. Media daring sengaja meletakkan kata-kata hiperbola pada judul berita, agar lebih menarik perhatian pembaca. Beberapa jurnalis media daring terkadang sengaja membuat judul yang terkesan berlebihan walaupun sebenarnya berisi kebohongan atau penipuan.

Salah satu contoh kasus dari jebakan klik adalah akun Facebookbernama Merdeka. com, yang mana pada tanggal 7 September membagikan tautan berita yang berjudul "Selain Raisa, Ternyata di Hati Hamish Ada 3 Wanita Cantik Ini”. Berita ini membuat seolah-olah Hamish memiliki wanita lain padahal ia baru saja menikah dengan penyanyi Raisa. Ketiga wanita lain yang dimaksud sebenarnya adalah adik kandung dari Hamish (https://www.Facebook.com/ MDKcom/). Judul berita yang ambigu tersebut, sukses memperoleh perhatian pembaca yang haus akan berita hubungan Hamish dan Raisa yang menjadi trending topic pada saat itu.

Maraknya jebakan klik memicu banyaknya aduan dari masyarakat terkait media massa. Sebanyak 750 aduan telah diterima Dewan Pes sepanjang tahun 2016 (Ramadhan, 2017). Sejumlah 90\% terlapor adalah media massa utama dan $10 \%$ sisanya adalah media abal-abal.Dari 14.00o lebih jumlah media daring yang ada di Indonesia, baru 5\% saja yang melapor kepada Dewam Pers sebagai media daring. 95\% sisanya merasa belum perlu atau tidak mengetahui pentingnya mendaftarkan media daringnya pada Dewan Pers (Nugraheny, 2016).

Jebakan klik pada dasarnya masih menjadi kasus media daring yang cukup sulit untuk diatasi secara keseluruhan. Kasus ini memanfaatkan kelemahan pembaca untuk mendapatkan keuntungan pribadi. Kerugian dari jebakan klik memang tidak secara langsung mempengaruhi pola komunikasi pembaca, akan tetapi kualitas informasi yang menurun tentu saja akan berpengaruh terhadap produktifitas para pembaca yang menggantungkan informasi pada media daring. Demi memberantas banyaknya kasus jebakan klik, diperlukan peran serta berbagai pihak agar kasus ini dapat segera selesai. Pembaca harus sadar dan tidak mudah terpancing oleh judul-judul berita di media daring. Penyaringan informasi dari kesadaran pribadi memang sangat dibutuhkan agar jebakan klik tidak 'semakin subur' di media daring.

Selain pembaca, pembuat berita media daring harusnya sadar bahwa jebakan klik merupakan tindakan yang melanggar kode etikjurnalistikkarenamembohongipembaca. Menggunakan judul yang mempresentasikan isi, harus menjadi fokus utama agar pembaca tidak merasa dirugikan dan tetap memercayai media daring sebagai sumber informasi terpercaya. Mendaftarkan media daringnya pada Dewan Pers juga menjadi salah satu solusi untuk meningkatkan kredibilitas informasi. Banyaknya kunjungan pembaca secara otomatis akan terbentuk walaupun media daring tidak menggunakan jebakan klik. Pembaca akan mampu menilai, mana media daring yang berkualitas dan jujur kepada pembaca. Membuat judul berita yang sesuai dengan isi, tidak menggunakan jebakan klik, terdaftar sebagai media daring pada Dewan Pers, dan menerapkan kode etik jurnalistik secara baik, adalah salah satu bentuk rasa loyalisme jurnalis pada media massa dan juga pembaca. Media massa yang sedemikian rupa tentunya adalah media massa yang layak untuk dibaca dan dibagikan di media sosial karena kualitas berita dan sumber beritanya yang terpercaya. 


\section{Ujaran Kebencian dalam Media Sosial}

Adanya media sosial memberikan pengaruh yang cukup signifikan bagi kehidupan masyarakat. Tidak hanya untuk bersosialisasi dan berkomunikasi, media sosial kini telah berubah menjadi sebuah wadah untuk beraspirasi dan berpartisipasi dalam berbagai kegiatan dan keperluan. Dengan berbagai kemudahan yang diberikan oleh media sosial, ternyata tidak semuanya dapat dimanfaatkan secara bijak oleh pengguna. Pada dekade belakangan ini saja, banyak kasus yang disebabkan oleh adanya media sosial. Rata-rata, kasus yang terjadi adalah penyampaian ujaran kebencian yang dilakukan oleh pihakpihak tertentu yang merasa kontra dengan sesuatu yang dibencinya tersebut. Ujaran kebencian ini biasanya dilontarkan dalam sebuah ruang publik atau public sphereyang berwujud media sosial. Network public sphere merupakan sebuah ruang publik yang cukup luas, memiliki jaringan, dan saling bertautan satu sama lain.Networked public sphere bukan hanya menjadi wadah masyarakat untuk berkomunikasi tetapi juga untuk menciptakan demokrasi, kebebasan berdiskusi, dan kesempatan mengkritik.

Benkler (2006:10-16) menjelaskan bahwa networked public sphere merupakan sebuah 'tempat' yang cukup rawan akan berbagai masalah. Adanya Networked public sphere memungkinkan banyaknya informasi yang berlalu-lalang diinternet menurun kredibilitas informasinya karena sumber informasi yang tidak jelas. Banyaknya informasi yang berbeda tentang suatu peristiwa yang sama, semakin memunculkan keraguan pembaca terhadap beritayangada di media sosial. Adanya rumor, hoax, dan gossip yang beredar, akan dengan mudah memicu banyaknya ujaran kebencian pada berbagai media sosial. Disaat semua orang seolaholah mampu berbicara, mampu menulis, dan mampu membuat berita, lalu siapa yang akan mendengar dan membaca berita yang mereka ciptakan sendiri? Fenomena inilah yang disebut Benkler dengan babel objection.

Sosial media seperti Facebook dan WhatsApp menjadi alat yang paling laris dimedia sosial untuk menyebarkan berita hoaks dan ujaran kebencian. Di Indonesia sendiri, pelaporan kasus ujaran kebencian mencapaiangka 671 kasus pada tahun 2015 dan 2016. Dari jumlah tersebut, hanya 199 kasus yang sudah ditangani oleh pihak kepolisian (Vatvani, 2017). Dalam rapat terbatasnya ditahun 2016, Presiden Joko Widodo secara khusus membahas tentang perkembangan media sosial. Beliau menyampaikan bahwa media daring yang menampilkan berita hoaks, berjudul provokatif, dan mengandung fitnah harus ditindak secara tegas (Sa'diyah, 2016).

Dari situs http://icjr.or.id/edaranpenangkal-kebencian yang di posting pada tanggal 8 November 2015, terdapat sebuah contoh kasus penyampaian ujaran kebencian pada media sosial Facebook yang dilakukan oleh akun bernama Arif Kusnandar pada bulan Agustus 2015. Dalam kasus tersebut, Arif Kusnandar menulis status di Facebook menggunakan bahasa yang kasar dan tidak sopanyang mana berisi makian dan menghina warga negara Indonesia keturunan Tionghoa. Ia mengaitkanadanya warga negera Indonesia keturunan Tionghoa dengan krisis ekonomi yang pernah terjadi ditahun 1990an. Pemilik akun tersebut bahkan mengancam jika nilai tukar Dollar Amerika Serikat menembus angka Rp. 15.000,oo, maka kerusuhan seperti pada tahun 1998 akan terulang kembali.

Adanya status tersebut langsung saja menarik perhatian para pengguna Facebook. Sebuah forum komunitas daring bernama Forum Demokrasi Digital bahkan menggalang petisi dengan judul "Stop Kebencian Rasial” di situs Change.org. Petisi tersebut bertujuan untuk melawan hasutan status Arif Kusnandar pada media sosial Facebook yang dianggap telah mencemarkan dan merendahkan martabat Warga Negara Indonesia keturunan Tinghoa. Secara tidak terduga, petisi tersebut ternyata menarik perhatian banyak sekali pengguna Facebook sehingga dalam waktu 24 jam saja telah mendapat dukungan 26 ribu lebih orang. Dukungan tersebut terus bertambah dan dalam waktu satu minggu saja, jumlah dukungannya mencapai angka 50 ribu orang. 
Kasus tersebut ternyata tidak hanya menarik perhatian pengguna media sosial Facebook. Kementerian Komunikasi dan Informastikaikut melaporkan kasus tersebut kepada pihak kepolisian. Status dari Arif Kusnandar dianggap telah mendiskriminasikan ras Tionghoa dan menimbulkan keresahan bagi masyarakat. Sayangnya, sampai saat ini kasus tersebut belum mempunyai hasil yang jelas. Tidak diketahui secara pasti hukuman apa yang diterima oleh Arif Kusnandar terkait kasus tersebut. Kita sebagai warga negara yang baik hanya dapat mempercayakan kasus ini kepada pihak yang berwenang yaitu kepolisian.

Selain kasus Arif Kusnandar yang pernah terjadi ditahun 2015, kasus ujaran kebencian juga marak terjadi belakangan ini. Pada kasus ini, terdapat sebuah ujaran kebencian tentang Presiden Joko Widodo (liputan6.com). Pelaku ujaran kebencian ditangkap karena mengunggah informasi yang dinilai tidak benar tentang Presiden Joko Widodo. Pelaku dijerat dengan Pasal 45 (2), Pasal 28 (2), dan Pasal 27 (2) UndangUndang Republik Indonesia Nomor 19 Tahun 2016 atas perubahan Undang-Undang Nomor 11 Tahun 2008 tentang informasi dan transaksi elektronik (ITE). Pelaku terancam enam tahun penjara. Selain itu, ada pula kasus ujaran kebencian yang korbannya adalah pemain bulutangkis asal Denmark. Dalam kasus tersebut, mereka mendapatkan ancaman pembunuhan di akun media sosial mereka. Pemain bulutangkis tersebut sangat marah dan berencana akan mempidanakan hal tersebut (Kosasih, 2017).Ancaman pembunuhan seperti kasus diatas tentunya harus segera ditindak secara tegas mengingat ancaman pembunuhan ini tidak hanya menjadi ujaran kebencian, tetapi sudah berubah menjadi kriminalitas.

Banyaknya kasus ujaran kebencian di media sosial disebabkan oleh sebuah situasi bernama liquid modernity. Liquid modernity (2008) menurut Knobel dan Lankshear adalah sebuah situasi dimana setiap individu membutuhkan kepuasan jangka pendek, tujuan tertentu yang sifatnya sementara, dan keinginan meraih suatu hal dalam waktu yang singkat. Situasi ini disebabkan oleh perubahan sosial karena teknologi berperan sebagai alat, perantara, dan hasil dari suatu peristiwa. Dalam banyaknya kasus ujaran kebencian, efek yang ditimbulkan dapat berupa kepuasaan pribadi dari pelaku atau bahkan keuntungan materil dari media massa yang dengan sengaja membuat kasus tersebut agar media massanya ramai dikunjungi oleh pembaca secara daring. Lebih jauh dari itu, ujaran kebencian pada media sosial terkadang menjadi salah satu strategi berpolitik untuk menjatuhkan lawan politik dari orang-orang yang berkepentingan. Hal ini menjadi salah satu alasan mengapa masyarakat 'enggan' untuk percaya $100 \%$ pada berita di media sosial. Hal tersebut tentunya sangat beralasan mengingat kemajuan teknologi dan media sosial yang terjadi pada saat ini, tidak dapat disikapi secara bijaksana oleh semua pihak.

\section{Hukum Negara dalam Pencegahan dan Penanganan Ujaran Kebencian}

Dalam upaya mencegah dan menangani ujaran kebencian yang marak terjadi di media sosial, pemerintah sebenarnya telah lama merumuskan beberapa aturan yang dinilai dapat menangani hal-hal tersebut. Aturan yang telah dibuat ada yang berbentuk Undang-Undang,ada juga yang berbentuk Surat Edaran. Aturan-aturan tersebut pada dasarnya dibuat sebagai tindakan pencegahan agar ujaran kebencian tidak banyak di diutarakan oleh warga net kepada orang lain. Dengan adanya aturan-aturan yang sifatnya mengikat, diharapkan warga net akan lebih bijak dalam menggunakan media sosial meskipun terdapat kebebasan mengeluarkan pendapat sesuai yang diamanatkan oleh Undang-Undang Dasar 1945. Jika ternyata aturan-aturan tersebut masih belum dapat mencegah ujaran kebencian secara keseluruhan, maka pemerintah akan membuat aturan yang sifatnya lebih kuat agar dapat menimbulkan efek jera bagi pelaku dan memberikan pembelajaran bagi masyarakat agar tidak melakukannya. 
Salah satu contoh Undang-Undang yang membahas mengenai ujaran kebencian adalah Undang-Undang Informasi dan Transaksi Elektronik. Undang-Undang Informasi dan Transaksi Elektronik sebenarnyatelah dibuat sejak tahun 2008. Undang-Undang Informasi dan Transaksi Elektronik ini dibuatoleh pemerintah dengan tujuan melindungi warga net dari penipuan dalam belanja daring dan perbuatan tidak menyenangkan yang terjadi di media daring dan media sosial. Penjelasan pasal mengenai ujaran kebencian adalah sebagai berikut:

Undang-UndangNomorıTahun2oo8tentang Informasi dan Transaksi Elektronik: 1. Pasal 27 (3)

Setiap orang dengan sengaja dan tanpa hakmendistribusikan dan/atau mentransmisikan dan/ataumembuat dapat diaksesnya informasi elektronik dan/atau dokumen elektronik yang memiliki muatan penghinaan dan/atau pencemaran nama baik.

2. Pasal 27 (4)

Setiap orang dengan sengaja dan tanpa hak mendistribusikan dan/atau mentransmisikan dan/atau membuat dapat diaksesnya informasi elektronik dan/atau dokumen elektronik yang memiliki muatan pemerasan dan/atau pengancaman.

\section{Pasal 28(2)}

Setiap orang dengan sengaja dan tanpa hak menyebarkan informasi yang ditujukan untuk menimbulkan rasa kebencian atau permusuhan individu dan/atau kelompok masyarakat tertentu berdasarkan atas suku, agama, ras, dan antargolongan (SARA).

\section{Pasal 45 (1)}

Setiap orang yang memenuhi unsur sebagaimana dimaksud dalam Pasal 27 ayat (1), ayat (2), ayat (3), atau ayat (4) dipidana dengan pidana penjara paling lama 6 (enam) tahun dan/atau denda paling banyak Rp1.000.000.000,00 (satu miliar rupiah).

\section{Pasal 45(2)}

Setiap orang yang memenuhi unsur sebagaimana dimaksud dalam Pasal 28 ayat (1) atau ayat (2) dipidana dengan pidana penjara paling lama 6 (enam) tahun dan/atau denda paling banyak $R p$
1.000.000.000 (satu miliar rupiah).

Di Indonesia, kasus penyebaran ujaran kebencian di media sosial telah meningkat secara pesat sejak tahun 2015. Hal ini telah mendorong pemerintah untuk merubah aturan dan memperketat Undang-Undang yang membahas tentang ujaran kebencian. Sejak disahkan, Undang-Undang Informasi dan Transaksi Elektronik telah mengalami perubahan dan revisi pada tanggal 27 Oktober 2016. Revisi tersebut baru akan berlaku 30 hari setelah Undang-Undang tersebut sah direvisi. Undang-Undang Informasi dan Transaksi Elektronik yang telah direvisi berlaku secara sah mulai tanggal 28 November 2016.

Secara rinci, perubahan UndangUndang tentang ujaran kebencian terdapat pada pasal 27 (3) yang berisi sebagai berikut:

1. Untuk menghindari multitafsir terhadap ketentuan larangan mendistribusikan, mentransmisikan dan/atau membuat dapat diaksesnya Informasi Elektronik bermuatan penghinaan dan/atau pencemaran nama baik pada ketentuan Pasal 27 ayat (3), dilakukan 3 (tiga) perubahan sebagai berikut:

a. Menambahkan penjelasan atas istilah "mendistribusikan, mentransmisikan dan/atau membuat dapat diaksesnya Informasi Elektronik".

b. Menegaskan bahwa ketentuan tersebut adalah delik aduan bukan delik umum.

c. Menegaskan bahwa unsur pidana pada ketentuan tersebut mengacu pada ketentuan pencemaran nama baik dan fitnah yang diatur dalam KUHP.

2. Menurunkan ancaman pidana pada 2 (dua) ketentuan sebagai berikut:

a. Ancaman pidana penghinaan dan/atau pencemaran nama baik diturunkan dari pidana penjara paling lama 6 (enam) tahun menjadi paling lama 4 (tahun) dan/atau denda dari paling banyak $R p 1$ miliar menjadi paling banyak Rp 750 juta.

b. Ancaman pidana pengiriman 
informasi elektronik berisi ancaman kekerasan atau menakut-nakuti dari pidana penjara paling lama 6 (enam) tahun menjadi paling lama 4 (empat) tahun dan/atau denda dari paling banyak $R p 2$ miliar menjadi paling banyak Rp 750 juta.

3. Menambahkan ketentuan mengenai "right to be forgotten" atau "hak untuk dilupakan" pada ketentuan Pasal 26, sebagai berikut:

a. Setiap Penyelenggara Sistem Elektronikwajib menghapus Informasi Elektronik yang tidak relevan yang berada di bawah kendalinya atas permintaan orang yang bersangkutan berdasarkan penetapan pengadilan.

b. Setiap Penyelenggara Sistem Elektronik wajib menyediakan mekanisme penghapusan Informasi Elektronik yang sudah tidak relevan.

Berlakunya Undang-Undang Informasi dan Transaksi Eelektronik ini didukung penuh oleh Ketua Komisi I DPR, Abdul Kharis Almasyhari (Sutrisno, 2016). Beliau menghimbau agar masyarakat tidak menggunggah sesuatu yang dapat menyinggung orang lain. Dengan berlakunya Undang-Undang ini, maka segala bentuk ujaran kebencian di media sosial telah dilarang secara sah di Indonesia.

Selain Undang-Undang Informasi dan Transaksi Elektronik, aturan lain yang berkaitan dengan kasus ujaran kebencian di media sosial adalah Surat Edaran Kepala Kepolisian Republik Indonesia Tahun 2015. Surat Edaran tersebut dibuat oleh Drs. Badrodin Haiti yang menjabat sebagai Kepala Kepolisian Republik Indonesia pada saat itu. Surat Edaran Nomor: SE/o6/X/2015 Tentang Penanganan Ujaran Kebencian (Hate Speech) ini secara jelas menjelaskan tentang halhal yang dianggap ujaran kebencian dalam angka 2, sebagai berikut:

(f) bahwa ujaran kebencian dapat berupa tindak pidana yang diatur dalam Kitab Undang-Undang Hukum Pidana (KUHP) dan ketentuan pidana lainnya di luar KUHP, yang berbentuk antara lain:
1. penghinaan;

2. pencemaran nama baik;

3. penistaan;

4. perbuatan tidak menyenangkan;

5. memprovokasi;

6. menghasut;

7. penyebaran berita bohong; dan semua tindakan di atas memiliki tujuan atau bisa berdampak pada tindak diskriminasi, kekerasan, penghilangan nyawa, dan/atau konflik sosial.

(g) bahwa ujaran kebencian sebagaimana dimaksud di atas, bertujuan untuk menghasut dan menyulut kebencian terhadap individu dan/atau kelompok masyarakat dalam berbagai komunitas yang dibedakan dari aspek:
1. suku;
2. agama;
3. aliran keagamaan;
4. keyakinan/kepercayaan;
5. ras;
6. antar golongan;
7. warna kulit;
8. etnis;
9. gender;
10. kaum difabel (cacat);
11. orientasi seksual;

(h) bahwa ujaran kebencian (hate speech) sebagaimana dimaksud di atas dapat dilakukan melalui berbagai media, antara lain:

1. dalam orasi kegiatan kampanye;

2. spanduk atau banner;

3. jejaring media sosial;

4. penyampaian pendapat di muka umum (demonstrasi);

5. ceramah keagamaan;

6. media masa cetak maupun elektronik;

7. pamflet;

Berdasarkan isi Surat Edaran tersebut dapat kita ketahui bentuk, tujuan, dan media apa ujaran kebencian disampaikan. Jika ujaran kebencian dianggap telah menimbulkan tindak diskriminasi, 
kekerasan, penghilangan nyawa, dan/atau konflik sosial yang meluas, maka diperlukan langkah-langkah penanganan seperti yang dijelaskan pada Surat Edaran Nomor: SE/o6/X/2015 Tentang Penanganan Ujaran Kebencian (Hate Speech) angka 3, yaitu:

a. Melakukan tindakan preventif sebagai berikut:

1) setiap anggota Polri agar memiliki pengetahuan dan pemahaman mengenai bentuk-bentuk ujaran kebencian yang timbul di masyarakat;

2) melalui pemahaman atas bentukbentuk ujaran kebencian dan akibat yang ditimbulkannya maka personil Polri diharapkan lebih responsif atau peka terhadap gelaja-gejala yang timbul di masyarakat yang berpotensi menimbulkan tindak pidana ujaran kebencian;

3) setiap anggota Polri agar melakukan kegiatan analisis atau kajian terhadap situasi dan kondisi di lingkungannya masing-masing terutama yang berkaitan dengan perbuatan ujaran kebencian;

4) setiap anggota Polri agar melaporkan kepada pimpinan masing-masing atas situasi dan kondisi di lingkungannya terutama yang berkaitan dengan perbuatan ujaran kebencian;

5) kepada para Kasatwil agar melakukan kegiatan:

a) mengefektifkan dan mengedepankan fungsi intelijen untuk mengetahui kondisi real di wilayah-wilayah yang rawan konflik terutama akibat hasutanhasutan atau provokasi, untuk selanjutnya dilakukan pemetaan sebagai bagian dari early warning dan early detection;

b) mengedepankan fungsi binmas dan Polmas untuk melakukan penyuluhan atau sosialisasi kepada masyarakat mengenai ujaran kebencian dan dampakdampak negatif yang akan terjadi;

c) mengedepankan fungsi binmas untuk melakukan kerja sama yang konstruktif dengan tokoh agama, tokoh masyarakat, tokoh pemuda, dan akademisi untuk optimalisasi tindakan represif atas ujaran kebencian;

d) apabila ditemukan perbuatan yang berpotensi mengarah pada tindak pidana ujaran kebencian maka setiap anggota Polri wajib melakukan tindakan:

(1) memonitor dan mendeteksi sedini mungkin timbulnya benihpertikaian di masyarakat;

(2) melakukan pendekatan pada pihak yang diduga melakukan ujaran kebencian;

(3) mempertemukan pihak yang diduga melakukan ujaran kebencian dengan korban ujaran kebencian;

(4) mencari solusi perdamaian antara pihak-pihak yang bertikai; dan

(5) memberikan pemahaman mengenai dampak yang akan timbul dari ujaran kebencian di masyarakat;

Apaila tindakan preventif ini sudah dilakukan oleh anggota Polri namun tidak menyelesaikan masalah ujaran kebencian, maka penyelesaian lainnya dapat dilakukan sesuai dengan:

- Kitab Undang-Undang Hukum Pidana (KUHP) yang berhubungan dengan ujaran kebencian,

- UU Nomor 11 Tahun 2008 tentang Informasi dan Transaksi Elektronik,

- UU Nomor 40 Tahun 2008 tentang Penghapusan Diskriminasi Ras dan Etnis,

- UU Nomor 7 Tahun 2012 tentang Penanganan Konflik Sosial, dan

- Peraturan Kepala Kepolisian Negara Republik Indonesia Nomor 8 Tahun 2013 tentang Teknis Penanganan Konflik Sosial.

Dalam unggahannya pada tanggal 6 November 2015, www.hukumonline.com 
justru berpendapat bahwa adanya Surat Edaran Nomor: SE/o6/X/2015 Tentang Penanganan Ujaran Kebencian (Hate Speech) ini, telah memberikan celah kepada pelaku pengujar kebencian untuk bisa lepas dari jeratan hukum dengan meminta anggota Polri untuk mempertemukan pelaku dengan korban, mencari solusi perdamaian, dan memberikan pemahaman mengenai dampak ujaran kebencian yang terlanjur dilontarkan sesuai dengan isi pada angka 3 Surat Edaran tersebut. Hal ini tentunya tidak dapat dibiarkan begitu saja mengingat efek dari ujaran kebencian yang bisa saja mencemarkan nama baik korban dan membuat korban disalahpahami oleh masyarakat yang terlanjur mempercayai ujaran kebencian tersebut.

Secara keseluruhan, Surat Edaran tersebut sebenarnya sudah berfungsi sebagaimana mestinya. Secara hukum surat edaran memang hanya berlaku secara internal sesuai dengan kewenangan dari pembuat surat edaran. Hal ini tentu saja berbeda dari Undang-Undang yang sifatnya mengikat dan sah dimata hukum. Adanya Surat Edaran Nomor: SE/o6/X/2015 Tentang Penanganan Ujaran Kebencian (Hate Speech) ini memang dibuat oleh Kapolri untuk menginstruksi anggotanya agar memahami apa itu ujaran kebencian dan dapat memberikan tindakan preventif agar ujaran kebencian tidak terjadi kembali dikemudian hari. Jika surat edaran ini ternyata belum bisa menangani masalah ujaran kebencian, maka pelaku akan tetap dijerat sesuai Undang-Undang Informasi dan Transaksi Elektronik atau Undang-Undang lain yang dianggap mendukung penyelesaian kasus yang ada.

Keseluruhan peraturan tentang pencegahan dan penanganan ujaran kebencian, pada dasarnya telah disusun oleh pemerintah guna menyelesaikan kasus-kasus yang ada. Apapun bentuknya, aturan-aturan tersebut tetap bertujuan untuk menuntaskan masalah ujaran kebencian yang marak terjadi belakangan ini. Yang seharusnya menjadi fokus perhatian pada saat ini adalah bagaimana cara mencegah agar kasus ujaran kebencian tidak terjadi kembali. Diperlukan peran serta pemerintah dan masyarakat agar media sosial tidak disalah gunakan lagi sebagai media untuk melontarkan ujaran kebencian yang dapat merugikan orang lain.

Salah satu solusi untuk menangani masalah ujaran kebencian pada media sosial adalahdengan memberikan pengetahuandan pemahaman mengenai literasi digital. Secara umum, yang dimaksud dengan literasi digital adalah kemampuan untuk memperoleh, memahami, dan memproduksi informasi dalam bentuk digital secara bijak. Literasi digital ini dapat berperan sebagai 'kompas' bagi warga net agar dapat bersosialisasi di media sosial secara lebih nyaman.

\section{Mencerdaskan Masyarakat Melalui Literasi Digital}

Kemajuan teknologi informasi dalam berbagai bentuk, secara tidak langsung telah mendorong kemajuan pola peradaban manusia. Perubahan cara berkomunikasi, kemudahan akses informasi, hingga berbagai kasus yang muncul karena penyalahgunaan media sosial, menjadi salah satu bukti bahwa masyarakat telah bertransformasi menjadi manusia berperadaban tinggi. Peradaban tinggi yang dimaksud tentunya akan membawa dampak pada kemampuan untuk memahami dan menyikapi berbagai informasi yang diterima.

Informasi dalam berbagai bentuk, mulai dari tercetak, elektronik, hingga digital tentunya membawa dampak yang berbeda-beda terhadap pola kehidupan bermasyarakat. Di antara bentuk-bentuk tersebut, informasi dalam bentuk digital menjadi salah satu sumber dari berbagai masalah sosial yang ada di masyarakat. Dibutuhkan kebijaksanaan dari para pengguna untuk lebih memahami dan menyaring setiap informasi yang diperoleh. Hal inilah yang kemudian dinamakan literasi digital.

Literasi digital menurut Gilster\& Glister (1997) adalah kemampuan untuk memahami dan menggunakan informasi dari berbagai sumber yang disajikan dalam bentuk digital. Berliterasi digital tentunya tidak hanya 
sekedar membaca berita di media sosial, akan tetapi memahami dan menggunakan informasi yang diterima secara lebih bijaksana. Masyarakat berliterasi tentunya akan mampu memahami pesan tersirat dan pesat tersurat dari setiap berita daring yang diterima. Tidak hanya percaya pada sumbernya, tetapi juga membuat banding secara logis dengan berita lain yang sejenis. Gilster\& Gilster lebih fokus pada pemikiran kritis dalam mencari, menggunakan informasi, serta mengevaluasi dan menyimpulkan informasi yang didapat. Ini berarti bahwa literasi digital membutuhkan kemampuan penguasaan teknologi, kompetensi menganalisa informasi, kemampuan berkomunikasi efektif, dan menikmati karya visual.

Literasi digital membuat masyarakat dapat mengakses, memilah dan memahami berbagai jenis informasi guna meningkatkan kualitas hidup. Literasi digital juga digunakan untuk mendidik masyarakat agar dapat berpartisipasi dalam kehidupan bermasyarakat, bernegara dan berpolitik dengan menyampaikan aspirasinya secara baik dan terstruktur di kanal-kanal daring tertentu. Dengan berkembangnya kemampuan menelaah, mengevaluasi dan menggunakan informasi, maka warga net akan mampu beropini dengan cara yang lebih baik. Selain itu, warga net juga tidak boleh termakan provokasi media daring yang disebarkan melalui media sosial agar ujaran kebencian dapat menurun popularitasnya dan pola pikar masyarakat dapat lebih terbuka.

UNESCO (Glagiardone, et al., 2015) memiliki program untuk menangani ujaran kebencian yang terjadi di media sosial dan media daring. Program tersebut akan mengarahkan dan mengidentifikasi adanya ujaran kebencian sekaligus melatih warga net untuk mengatasi ujaran kebencian tersebut. UNESCO menekankan pada pendidikan kepada warga net agar dapat menggunakan media sosial untuk beragumentasi dan menyampaikan pendapatnya secara terstruktur tanpa implikasi kebencian terhadap pihak manapun. Pendidikan dan sosialisasi terhadap dampak ujaran kebencian, sangat per- lu untuk diberikan kepada warga net agar mereka mengetahui konsekuensi yang akan mereka peroleh apabila mengeluarkan ucapan penuh kebencian. Media massa pun tidak boleh menutup mata terhadap maraknya fenomena ini. Media massa pun dihimbau untuk mengontrol setiap isi berita yang mereka tayangkan.

Bukan hanya UNESCO yang memiliki program peningkatan literasi digital, pemerintah Indonesia pun juga mulai menyosialisasikan pentingnya literasi digital bagi masyarakat. Pada tahun 2017, Kementerian Pendidikan dan Kebudayaan telah menerbitkan modul panduan teknis yang berjudul "Pendidikan Keluarga di Era Digital" dengan sasaran 6o kabupaten dan/atau kota. Selain pemerintah, Non-Government Organization (NGO) bernama Project Child Indonesia, telah melakukan kegiatan Internet Literacy Program bagi murid sekolah dasar di Yogyakarta (projectchild.ngo). Dengan adanya program literasi digital sejak dini, diharapkan akan lebih membantu warga net untuk lebih siap dalam menerapkan kemampuan berliterasi mereka dimasa depan. Jika literasi digital warga net sudah baik, maka kenyamanan di dunia siber dapat terbentuk secara maksimal demi keamanan lingkungan, dan masa depan bangsa.

Kepedulian pemerintah terhadap efek media daring, membuat pemerintah secara agresif membuat peraturan yang berusaha untuk melingungi masyarakat dari kejahatan media sosial. Presiden juga menghimbau secara langsung kepada masyarakat untuk bersikap lebih bijak dalam mengunggah atau berkomentar di laman media sosial. Presiden juga menghimbau untuk tidak mengunggah foto yang memprovokasi, agar kejahatan akibat media sosial dapat diminimalisir. (Sa'diyah, 2016).

\section{SIMPULAN}

Komunikasi banyak arah telah membuat para pengguna internet menjadi seorang prosumer. Prosumer berasal dari istilah production by consumers (Toffler, 1980), yang berarti usaha seseorang untuk mengonsumsi 
sekaligus memproduksi sesuatu sehingga peran penyedia informasi dan pengonsumsi informasi menjadi buram. Kemampuan membuat sekaligus mengonsumsi informasi menjadi ladang subur bagi masyarakat untuk berjurnalisme secara daring.

Pada saat ini bukan hanya jurnalis saja yang mampu memproduksi berita, tetapi setiap orang dapat membuat dan menyebarkan berita itu baik berupa fakta atau opini. Banyaknya warga net yang bisa memproduksi dan menyebarkan informasi, membuat media daring tidak ingin berkalah saing untuk mendapatkan perhatian pembaca. Media daring banyak menggunakan teknik jebakan klik dengan menuliskan judul berita yang cenderung berlebihan dan tidak sesuai dengan isi berita agar mendapatkan banyak pembaca. Semakin banyak jumlah pembaca, maka akan semakin banyak pula uang yang akan mereka dapatkan.

Tingginya angka penggunaan media daring untuk bersosialisasi, membuat perkembangan media sosial seakan tidak terkontrol. Media sosial seolah berubah menjadi pusat berbagai macam aktivitas manusia. Media sosial menjadi tempat yang sangat strategis untuk membagikan berbagai cerita mulai dari cerita sehari-hari, hingga ujaran kebencian yang bersifat pribadi. Segala macam bentuk ujaran kebencian tersebut akhirnya dapat menggiring opini publik tentang suatu hal, meskipun hal tersebut belum tentu benar adanya. Dalam hal ini, media daring bagaikan 'pedang bermata dua' yang mempunyai sisi positif dan negatif dalam waktu yang bersamaan.

Jika berbagai masalah akibat penyalahgunaan media sosial telah muncul, maka pemerintah mempunyai peran paling besar dalam menangani permasalahan yang ada. Pemerintah seharusnya dapat membuat suatu aturan yang bersifat mengikat dan menimbulkan efek jera bagi para pelaku yang melanggarnya. Untuk itu, pemerintah Indonesia akhirnya membuat Undang-Undang Informasi dan Transaksi Elektronik guna melindungi masyarakat dari penyalahgunaan informasi di internet.
Undang-Undang ini telah dibuat sejak tahun 2008 dan telah mengalami revisi guna menyesuaikan keadaan yang ada. UndangUndang Informasi dan Transaksi Elektronik ini telah disahkan sejak 27 Oktober 2016 dan mulai diberlakukan 30 hari setelah undang-undang tersebut disahkan, yaitu 28 November 2016.

Selain Undang-Undang tersebut, terdapatpulaSuratEdaran Nomor:SE/o6/X/2015 yang berisi tentang Penanganan Ujaran Kebencian (Hate Speech). Surat Edaran ini dibuat oleh Kepala Kepolisian Republik Indonesia, Drs. Badrodin Haiti di tahun 2015. Surat edaran tersebut menginstruksikan kepada seluruh anggota Polri untuk melakukan berbagai tindakan yang dianggap perlu jikalah terjadi kasus ujaran kebencian. Adanya hal ini terkadang malah memberikan celah bagi pelaku untuk meminta bantuan kepada anggota Polri untuk memediasi dan mendamaikan keduanya. Hal tersebut dapat dilakukan karena berdasar dari aturan yang ada pada surat edaran tersebut. Meskipun terdapat banyak celah dalam surat ini, surat edaran ini tetaplah hanya berlaku secara internal kepolisian dan memang menjadi tindakan preventif untuk menangani masalah ujaran kebencian yang marak terjadi di masyarakat akibat adanya penyalahgunaan media sosial/

Selain adanya hukum dari pemerintah, sebenarnya yang paling dibutuhkan masyarakat adalah kemampuan berliterasi secara digital. Literasi digital ini nantinya akan membantu masyarakat untuk lebih bijak dalam memproduksi, menggunakan, dan menyebarkan informasi di media daring secara lebih bijaksana. Dengan berkembangnya kemampuan menelaah, mengevaluasi dan menggunakan informasi, maka warga net akan lebih mampu untuk beropini dengan cara yang lebih baik dan di laman yang memang seharusnya. Masyarakat juga tidak akan mudah termakan provokasi yang disebarkan melalui media sosial sehingga ujaran kebencian akan menurun dan tercipta ketenangan di dunia siber Indonesia.

Jari selayak duri tidak lagi menjadi momok yang menakutkan bagi masyarakat 
Indonesia untuk bisa memproduksi dan mengkonsumsi informasi karena setiap berita yang dibuat telah dipertimbangkan kredibilitasnya. Dengan cara sedemikian rupa, proses mencerdaskan kehidupan bangsa dapat dilakukan secara optimal dengan kerjasama dari semua pihak. Mari bersama-sama berkontribusi, bukan hanya mengumbar berita iri. Jadikan media sosial sebagai wadah untuk bersosialisasi, bukan untuk menebar ironi. Demikianlah arti kemerdekaanyang sebenarnya, kemerdekaan dalam berinformasi dan berliterasi.

\section{DAFTAR PUSTAKA}

Anya, Agnes. (17 April 2017). Facebook User Reported After Claiming Gang Rape of Ahok Voter 'Halal'. Diakses dari http://www.thejakartapost.com/ news/2017/o4/17/Facebook-userreported-after-claiming-gang-rape-ofahok-voters-halal.html pada tanggal 20 Agustus 2017.

Benkler, Yochai. (2002). Coase'sPenguin, or Linux and The Nature of The Firm. Yale Law Journal, 112(3), 369-446.

Benkler, Youchai. (2006). The Wealth of Networks: How Social ProductionTransforms Markets and Freedom. New Haden and London: Yale University Press.

Gagliardone, Iginio, et al. (2015). Countering Online Hate Speech. France: UNESCO.

Gilster, P., \& Glister, P. (1997). Digital Literacy. New York: Wiley Computer Pub..

Ismarani, Dian. (2017). Data Pengguna Internet Tahun 2017 dan Apa Kesimpulan yang Bisa Diambil dari Data Tersebut. Diakses dari https:// www.youthmanual.com/post/fun/didyou-know/data-pengguna-internettahun-2017-dan-apa-kesimpulan-yangbisa-diambil-dari-data-tersebut pada tanggal 20 Agustus 2017.

Jenkins, Henry. (2006). Convergence Culture (Where Old Media Meets New Media). New York: New York University Press.

Kepolisian Negara Republik Indonesia. (2015). Surat Edaran Nomor: SE/o6/X/2015 Tentang Penanganan Ujaran Kebencian. Diakses dari http://cdn. bidhuan.id/img/2015/11/download287674212-Se-Hate-Speech-1.pdf pada 30 Oktober 2017.

Knobel, Michele \& Colin Lankshear. (2008). Digital Literacies: Concept, Policies, and Practices. New York: Peter Lang Publishing. 
Kosasih, Risa. (19 Juni 2017). Indonesia Open Ganda Putra Denmark Terima Ancaman Pembunuhan. Diakses dari http://bola.liputan6.com/ $\mathrm{read} / 2995766 /$ indonesia-open-gandaputra-denmark-terima-ancamanpembunuhan pada 1 Mei 2017.

Nugraheny, Dian Erika. (23 Desember 2016). AJI Sebut Baru 5 Persen Media Online Terdaftar di Dewan Pers. Diakses pada http://www.republika.co.id/berita/ nasional/umum/16/12/23/oin8e5361aji-sebut-baru-5-persen-media-onlineterdaftar-di-dewan-pers pada 20 Agustus 2017.

Nur, Mochamad. (26 Maret 2017). Siber Polri Beberkan Beda Aturan Hate Speech di Amerika dan Indonesia. Diakses dari https://www.jawapos.com/ $\mathrm{read} / 2017 / 03 / 26 / 118885 /$ siber-polribeberkan-beda-aturan-hate-speechdi-amerika-dan-indonesia pada 20 Agustus 2017.

Ramadhan, Bilal. (5 Januari 2017). Dewan Pers Terima 750 Aduan Selama 2016. Diakses pada http://nasional.republika. co.id/berita/nasional/umum/17/o1/o5/ oja1th330-dewan-pers-terimasebanyak-750-aduan-selama-2016 pada tanggal 20 Agustus 2017.

Sa'diyah, Halimatus. (29 Desember 2016). Jokowi Minta Media Online Dievaluasi. http://www.republika.co.id/berita/ nasional/umum/16/12/29/oixtxy382jokowi-minta-media-online-dievaluasi pada 20 Agustus 2017.

Sumadiria, AS Haris. (2006). Bahasa Jurnalistik: Panduan Praktis Penulis dan Jurnalis. Bandung: Simbiosa Rekatama Media.

Sutrisno, Elvan Dani. (28 November 2016). UU ITE Perubahan Berlaku, Komisi I DPR: Semua Jenis Hate Speech Dilarang. Diakses dari https://news.detik.com/ berita/d-3356323/uu-ite-perubahanberlaku-komisi-i-dpr-semua-jenishate-speech-dilarang pada 20 Agustus 2017.
Undang-Undang Republik Indonesia Nomor 11 Tahun 2008 Tentang Informasi dan Transaksi Elektronik.

Undang-Undang Republik Indonesia Nomor 19 Tahun 2016 Tentang Perubahan Atas Undang-Undang Nomor 11 Tahun 2008 Tentang Informasi dan Transaksi Elektronik.

Vatvani, Chadni. (27 Maret 2017). Hate Speech Most Reported Internet Crime in 2016: Indonesian Police. Diakses dari http://www.channelnewsasia. com/news/asiapacific/hate-speechmost-reported-internet-crime-in-2016indonesian-poli-8596724 pada tanggal 20 Agustus 2017.

[...]. (6 November 2015). Keberlakuan SE Kapolri Hate Speech dan Dampak Hukumnya. Diakses dari http://www. hukumonline.com/klinik/detail/ lt563accb796101/keberlakuan-sekapolri-hate-speech-dan-dampakhukumnyapada tanggal 30 Oktober 2017.

[...]. (8 November 2015). Edaran Penangkal Kebencian. Diakses dari http://icjr. or.id/edaran-penangkal-kebencian/ pada tanggal 30 Oktober 2017.

[...]. (21 Agustus 2017). Jeratan Hukum Para Penghina Presiden di Media Sosial. Diakses dari http://news.liputan6. com/read/3066985/jeratan-hukumpara-penghina-presiden-di-mediasosial pada tanggal 25 Agustus 2017. 
INFORMASI Kajian Ilmu Komunikasi Volume 47. Nomor 2. Desember 2017 